\title{
Gömör Béla professzor 80 éves
}

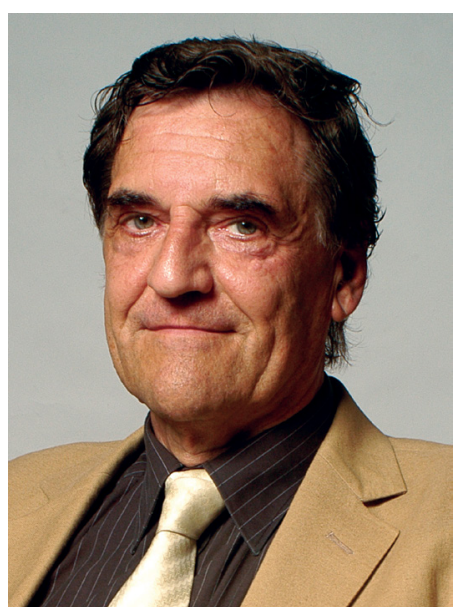

Gömör Béla, akit 34 éve neveztek ki egyetemi tanárrá, ez év január 23-án tölti be 80 . életévét. A köszöntést a volt munkatársak, a tanítványok és - reményeim szerint - az egész hazai reumatológustársadalom nevében írom, arra alapozva, hogy 34 évig dolgoztunk együtt, és osztályvezetői, valamint egyetemi oktatói minőségben is utóda lehettem.

Szegeden született, egyetemi tanulmányait is ott végezte, és szülővárosával máig sem szakadt meg kapcsolata.

40 éves korában lett osztályvezető, tudományos minősítést 41 éves korában szerzett (a spondylitis ankylopoetica genetikája), és tanszékvezető egyetemi tanári kinevezését 46 éves korában kapta meg.

Közelről figyelhettem meg, hogy vezetői múködése során mindent az optimális betegellátásnak rendelt alá, erôsen kézben tartva az orvosok és a szakszemélyzet szigorú rend szerinti múködését. A továbbiakban is erre az elvre épült a szak- és továbbképzést országosan irányító tevékenysége is.

1984-től 19 éven át volt a reumatológia és fizioterápia - Bozsóky Sándor professzor után - második, s akkoriban egyedüli tanszékvezető egyetemi tanára. Ezen idő alatt korát megelőzve - komoly követelményeket alakított ki a szakképzésben, minek következtében jelentősen emelkedett a szakorvosok elméleti és fóleg gyakorlati tudásszintje. Összességében 673 szakorvost vizsgáztatott, de még fontosabb volt a képzésük négy éven át történő gondos ellenőrzése, amely egy szúkebb szakterületen a személyes kapcsolatok és tekintély révén gördülékenyebb és hatékonyabb volt a mai, centralizált hivatali struktúránál.

Hazai és külföldi orvosi szaklapokban 121 közleménye jelent meg, melyek közül 1971 és 2006 között 44 foglalkozott kedvenc témájával, a spondylitis ankylopoeticával. Korszakos összefoglaló tanulmánya volt az Orvosi Hetilapban „A szelektív ciklooxigenáz (COX-2) gátlás” 1999-ben, más folyóiratban jelent meg 2004-ben az a közleménye, mely az első hazai beszámolót jelentette a biológiai terápiával elért eredményekról.
A szigorúan vett tudományos közleményeken kívül, kiterjedt publikációs aktivitást fejtett ki, írásainak a száma meghaladja a 200-at. Ezek között jelentős orvostörténeti munkák is szerepelnek.

1985 és 1996 között aktív tagja volt az MTA TMB I. számú szakbizottságának. Három akadémiai bizottságban szolgált mint tag, a Mozgásszervi Bizottságnak elnöke volt.

A Reumatológia és Fizioterápia Szakmai Kollégiumának 1987-1991 és 2000-2004 között volt elnöke, utóbbi periódusban az elnökök tanácsának tagja.

Gömör professzor nagy ambícióval végezte egyesületi vezetői munkáját. A Magyar Reumatológusok Egyesületét gyakorlatilag 1982-től 1996-ig vezette, az egyesületi élet területén jelentős megújulásokat (élénk tudományos élet, nemzetközi kapcsolatok kiépítése, szervezeti megújulás) kezdeményezve. 1991-ben sikerült Magyarországra hozni az elnöklésével lezajlott, több mint 4000 résztvevős európai reumatológiai kongresszust. A kongresszus sikerének köszönhetően egyrészt az európai szervezetnek 1991-1993 között megválasztott elnöke volt, másrészt a Magyar Reumatológusok Egyesületének - ritka kivételként - saját székháza lett. Öt nemzet reumatológiai egyesülete választotta tiszteleti tagjává.

Sokoldalúságát jelzi, hogy a szerteágazó orvosi tevékenység mellett érdekeset és maradandót alkotott a müvészetek (festészet, fotómúvészet) terén is. Húsz éven át szerkesztett egészen egyedi folyóiratot, orvosszakmai és múvészeti anyagokat egyaránt publikálva, három cím alatt, utoljára 2012-ig az Akadémiai Kiadó MediArt folyóirataként.

Könyvtermése minőségileg és mennyiségileg is jelentős. Három tankönyvet szerkesztett, ugyanakkor a medicina és múvészetek kapcsolatát tartalmazó köteteket jelentetett meg. Tizenkét kitüntetése közül kiemelendő a Széchenyi Professzori Ösztöndíj, valamint a felsőoktatás legmagasabb kitüntetése, a Szent-Györgyi Albert-díj.

Szerteágazó kultúrtörténeti munkásságából kiemelendő a fotómúvészet, festőmúvészet, kisplasztikai remekmúvek, emlékérmek, mütárgyak, egyéb képzőmüvészeti alkotások hű és odaadó bemutatása egyedi múfajú könyveiben, megmentve a feledéstől értékes, mesés munkásságokat. Élvezetes munkáiban a gondolatmenetére felfüzte és ezáltal összehozta a témába vágó, egyébként egymástól távol álló eseményeket, tárgyakat, személyeket. Szépirodalmi munkásságáért sok díjat kaphatott volna, maradt azonban az ezeknél sokkal fontosabb elismertség és népszerüség. Kiváló retorikai adottságú, választékos stílusú előadásait még sokáig szeretnénk élvezni, és kívánjuk, hogy továbbra is maradjon mindig vidáman a középpontban. Kedves Professzor Úr! Isten éltessen még sokáig!

Géher Pál dr. 